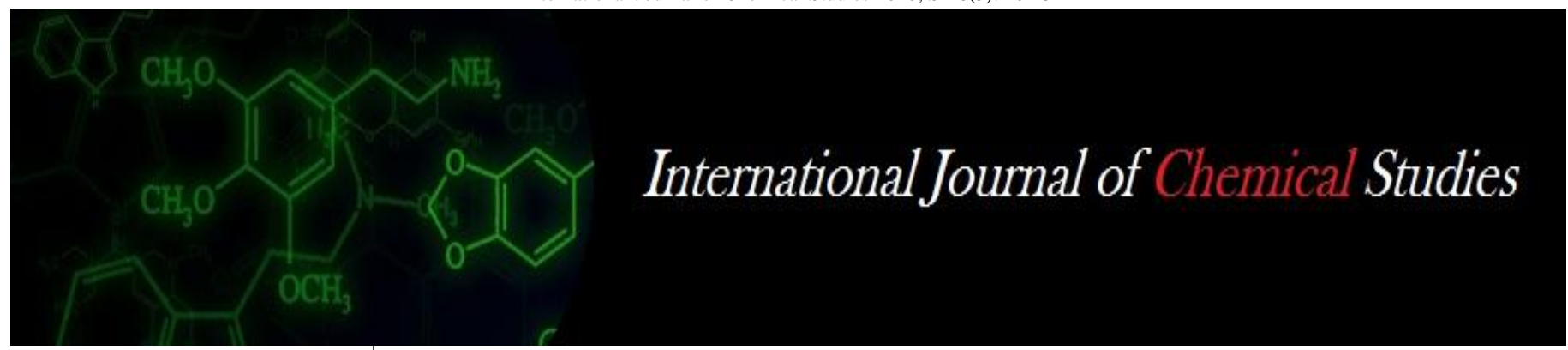

P-ISSN: 2349-8528

E-ISSN: 2321-4902

www.chemijournal.com

IJCS 2020; SP-8(3): 40-43

(C) 2020 IJCS

Received: 23-05-2020

Accepted: 26-06-2020

Himani Rawat

Department of Food Technology,

Uttaranchal School of Applied

and Life Sciences,

Uttaranchal University,

Dehradun, India

Mamta Sharma

Department of Food Technology,

Uttaranchal School of Applied

and Life Sciences,

Uttaranchal University,

Dehradun, India

Shilpa Sharma

Assistant professor, Uttaranchal

School of Applied and Life

Sciences, Uttaranchal

University, Dehradun, India

Corresponding Author:

AP Jadhav

Department of soil science and

Agricultural Chemistry,

Dr. Balasaheb Sawant Konkan

Krishi Vidyapeeth, Dapoli,

Maharashtra, India

\section{T.cordifolia: A medicinal plant}

\author{
Himani Rawat, Mamta Sharma and Shilpa Sharma
}

DOI: https://doi.org/10.22271/chemi.2020.v8.i4a.9855

\begin{abstract}
Tinospora cordifolia (TC) is a medicinal plant containing several nutritional properties. It is used as a therapeutic plant for treatment of fever, diarrhea, oral ulcer, diabetes, digestive disorder, urinary infections; jaundice and skin diseases etc. It is mainly used in Ayurveda and considered as a natural remedy for curing of various diseases. Giloy (T.cordifolia) is rich in nutritional and therapeutic values. It is consumed by the people in the form of decoction in cure certain ailments. The plant is well known for its phyto-chemical constituents.
\end{abstract}

Keywords: T.cordifolia, Giloy, Root extract, value added products

\section{Introduction}

Giloy is botanically known as Tinospora cordifolia (Wild) Miers ex hook.F. \& Thoms. Belongs to family Menispermaceae is a medicinal plant. India is known for medicinal plants since ancient times. Among them Giloy is one of the most commercially exploited plant in our Indian system (Singh and Warrior, 2004) ${ }^{[26]}$ and known as important constituent for many Ayurveda

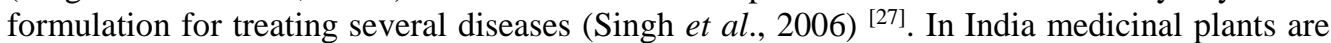
used as natural medicine since prehistoric times. Different parts of plants are used for medicinal purposes like crude extract due to presence of natural chemical constituents (Balandrin et al. 1985) ${ }^{[4]}$. T.cordifolia is used for the treatment of many health problems like diarrhea, jaundice, fever, diabetes, urinary issues, skin sicknesses etc.

It is found in India, China, Burma and Sri Lanka (Singh et al. 1984) ${ }^{[25]}$. It is a climber and mostly grows in warm climate. Neem, Jatropha and Moringa are used to provide support for its growth (Chaudhari and Shaikh, 2013) ${ }^{[5]}$. It is mostly cultivated in medium black or red soil but can also be grow in various types of soils which consist of sufficient moisture and organic rich material (Mittal et al. 2014) ${ }^{[14]}$

The exploration of active compounds in plant due to their biological function in disease control get interest in plant. The active compounds present in plant like alkaloids, steroids, diterpenoid lactones, aliphatics and glycosides have been confined from roots, stem and whole plant (Soham and Shyamasree, 2012) ${ }^{[30]}$.

Its fresh juice from stems and leaves is used as tonic for body pain (Soudamini et al. 2005) and also for treatment of asthma when consume orally with honey (Sinha et al. 2004) [29]. It regulating many disorders such as anti-oxidant, anti-hyperglycemic, anti-hyper lipidemia, hepato protective, cardiovascular protective, neuro protective, osteo protective, radio protective, anti-anxiety, adaptogenic agent, analgesic, anti-diarrheal, anti-ulcer, anti-microbial and anticancer agent (Dhama et al.; 2017) ${ }^{[6]}$

In Ayurveda T.cordifolia is consume in various dose forms like Kalka (paste of fresh stem), Churna (powdered dry stem), Swaras (juice from fresh stem), Kwatha (hot water extract from ground dried stem), Arishta (Stable processed formulation from a decoction of T.cordifolia containing self-generated alcohol) etc. (Panchabhai et al. 2008) ${ }^{[17]}$. Alcoholic extract obtained from the dried ripe fruits of T.cordifolia are good for immune modulatory activities (Aher and Wahi, 2010) ${ }^{[2]}$.

\section{Botanical Discription}

Botanical name of Giloy is Tinospora cordifolia (Wild) Miers ex hook.F. \& Thoms. It belongs to family Menispermaceae. It is a huge, globrous; deciduous broadly spreading climbing bush with a few stretched twinning branches. The stem of T.cordifolia is delicious with long 
Fili form, physical airborne roots from the branches. The bark is rich white to dark, the leaves are straight forward, interchange, extirpate, long petioles upto $15 \mathrm{~cm}$ long, roundish, pulvinate, both at the base and peak with the Basel one longer and curved in part and most of the way around. Lamina extensively applaud or praise cordite, $10-12 \mathrm{~cm}$ long or 8-10 $\mathrm{cm}$ broad,7 nerved and profoundly cordate at base, membranous, pubescent above, whitish tomentose with a noticeable reticulum underneath. The blossoms unisexual, little on isolated plants and showing up when plant is leafless, greenish yellow on axillary and terminal racemes.

\section{Nutritional Composition}

Giloy have high nutritional value containing 292.54 calories. (Nile and Khobragade, 2009). (Table 1) (Table 2)

Table 1: Mineral elements present in Giloy

\begin{tabular}{|c|c|}
\hline Mineral elements & Amount \\
\hline Potassium & $0.845 \%$ \\
\hline Iron & $0.28 \%$ \\
\hline Calcium & $0.131 \%$ \\
\hline Chromium & $0.006 \%$ \\
\hline
\end{tabular}

Table 2: Nutrients present in Giloy

\begin{tabular}{|c|c|}
\hline Nutrients & Amount \\
\hline Protein & $4.5-11.2 \%$ \\
\hline Carbohydrate & $61.66 \%$ \\
\hline Low fat & $3.1 \%$ \\
\hline Ash & $12.4 \%$ \\
\hline
\end{tabular}

\section{Natural products and their biological activities}

Active compounds or natural products isolated from T.cordifolia have many biological functions or activities which are given as follows:

Table 3: Natural components present in Giloy plant

\begin{tabular}{|c|c|c|c|}
\hline $\begin{array}{c}\text { Active } \\
\text { components/ } \\
\text { natural } \\
\text { components }\end{array}$ & $\begin{array}{c}\text { Plant } \\
\text { part }\end{array}$ & $\begin{array}{l}\text { Biological activity (in } \\
\text { human being) }\end{array}$ & Reference \\
\hline Alkaloids & $\begin{array}{l}\text { Root, } \\
\text { stem }\end{array}$ & $\begin{array}{l}\text { Anti-diabetes, } \\
\text { immunomodulatory, Anti- } \\
\text { viral functions, } \\
\text { inflammation }\end{array}$ & $\begin{array}{c}\text { Upadhaya. et al. } \\
(2010)^{[35]}, \\
\text { Rout(2006) }{ }^{[21]} \text {, } \\
\text { Patel. et al. (2009) } \\
\text { [20], } \\
\text { Gupta and Sharma } \\
\text { (2011) }{ }^{[7]}, \\
\text { Jagetia and } \\
\text { Rao(2006) }{ }^{[8],} \\
\text { Patel and } \\
\text { Mishra(2011) }\end{array}$ \\
\hline Steroids & Shoot & $\begin{array}{c}\text { IgA neuropathy, induced } \\
\text { cell cycle arrest in G2, M } \\
\text { phase and apoptosis through } \\
\text { c-Myc suppression, inhibit } \\
\text { TNF- } \alpha, \text { IL-6 and COX-2 }\end{array}$ & $\begin{array}{l}\text { Lv. et al. }(2012)^{[11]} \\
\text { Mckeown. et al. } \\
\text { (2012) }{ }^{[13]}, \\
\text { Sundarraj. et al. } \\
\text { (2012) }\end{array}$ \\
\hline Sesquiterpenoid & Stem & Antiseptic & $\begin{array}{c}\text { Maurya and Handa } \\
(1998)^{[12]}\end{array}$ \\
\hline Others & $\begin{array}{c}\text { Root, } \\
\text { whole } \\
\text { plant }\end{array}$ & $\begin{array}{c}\text { Protease inhibitors for HIV } \\
\text { and drug resistant HIV }\end{array}$ & $\begin{array}{l}\text { Kim. et al. }(2008) \\
\quad[10], \\
\text { Mukherjee. Et al. } \\
\quad(2010)^{[15]}\end{array}$ \\
\hline
\end{tabular}

\section{Properties}

\section{Osteoprotective activity}

During the experiment done on the mouse it is found that Tinospora cordifolia extract prevent the bone loss and also protect the animal from experimental estrogen deficiency induced by ovariectomy. It is concluded that T.cordifolia can be used for the treatment of bone fractures and inflammatory bone diseases in Indian ethnomedicine. T.cordifolia positively regulates the remodeling of bone and favored osteogenesis in vitro. (Abiramasundari et al. 2017) ${ }^{[1]}$

\section{Anti-diabetic activity}

T.cordifolia also acts as an anti-diabetic agent and is used for the treatment of diabetes mellitus. The anti-diabetic activity of T.cordifolia is due to presence of tannins, flavonoids, alkaloids, cardiac glycosides etc. (Anonymous, 2001) ${ }^{[3]}$. The leaf extract of plant is tested at different doses in alloxan-diabetic rabbit and it shows hypoglycemic effect positively (Wadood et al., 1992) ${ }^{[38]}$.

\section{Anti- HIV activity}

Kalikae et al. (2008) [9] reported that the stem extract of T.cordifolia reduces the ability of eosinophil count, stimulation of $\beta$-lymphocytes, macrophages, level of haemoglobin and polymorphonuclear Leucocytes.

\section{Immunomodulatory activity}

Sharma et al. (2011) ${ }^{[7]}$ and Upadhyay et al. (2011) said that a large variety of compounds which are responsible for immunomodulatory and cytotoxic effect are 11hydroxymuskatone, N-methyl-2-pyrrolidone, Nformylannonain, cordifolioside A, magnoflorine, tinocordioside and syringin. These natural compounds have been showed to improve the phagocytic activity of macrophages, enhancement in nitric acid production by stimulation of splenocyte.

\section{Anti-oxidant activity}

Gupta and Sharma (2011) ${ }^{[24]}$ stated that the T.cordifolia has the ability to scavenge free radical produced by aflatoxicosis. It showed protection against aflatoxin-induced nephrotoxicity due to the presence of alkaloids such as a choline, tinosporin, isocolumbin, palmatine, tetrahydropalmatine and magnoflorin.

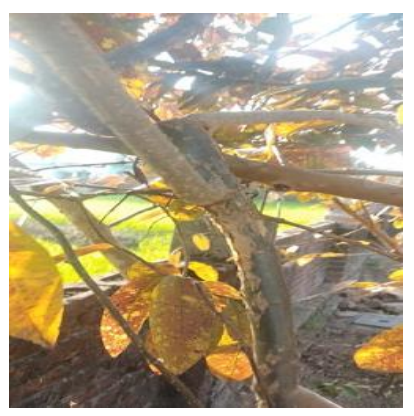

(a)

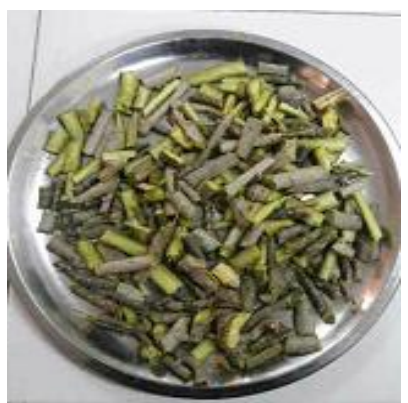

(b) 


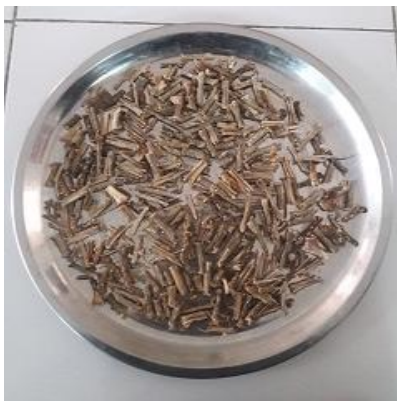

(c)

Fig 1: (a) Giloy plant (b) Giloy stem (c) Giloy dried stem

\section{Uses}

\section{Value added product}

Sood, (2016) ${ }^{[31]}$ from Hyderabad, India studied reported that prepared product has great nutritional value and can be organoleptically acceptable to the consumers. Giloy which contain high medicinal value can also be used for preparation of ready to eat and healthy products.

Sharma et al. (2013) ${ }^{[24]}$ from Karnataka, India reported that nutritional and medicinal properties of cookies can be improved by incorporation of dried Tinospora cordifolia leaf powder. Nutritional value of cookies is increased 0 to $7.5 \%$ by increase in iron, calcium, dietary fiber, protein, anti-oxidant activity and $\beta$-carotene by addition of Giloy dry leaves powder.

Sarala et al. (2012) ${ }^{[22]}$ stated that spray dried powder sample from leaf and stem of T.cordifoliahas high solubility. T.cordifolia not only contains various benefits and medicinal properties but can also be used in powder form for formulation of various health benefit food products.

Nile reported that medicinal plants G.sylvester, T.glaberrima, T.cordifoliaon dry matter basis have good nutritive value and can be used as food, fodder and livestock. It is good for younger and anemic people as it contains sufficient protein, carbohydrate with low fat and high fiber.

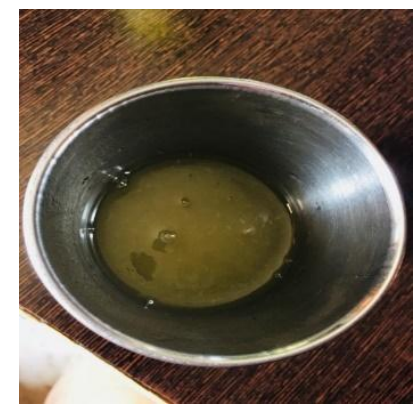

(a)

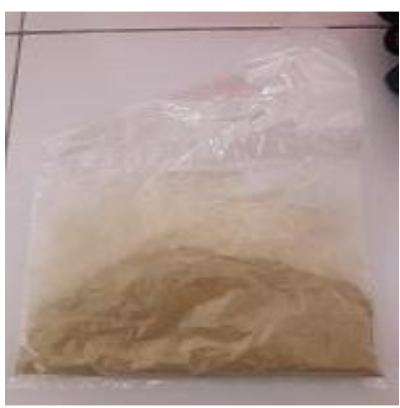

(b)

Fig 2: Giloy products (a) Giloy juice (b) Giloy powder

\section{Medicinal uses of Tinospora cordifolia}

- The juice of Tinospora cordifolia is beneficial for diabetes, dyspesia, vaginal and uretheral discharges (Singla et al.; 2010) ${ }^{[28]}$.

- The combination of giloy herb and tulsi leaves used against monkey malaria (Vashist et al.; 2011) ${ }^{[37]}$.

- In the presence of alkaloid in stem helps to regulate the blood sugar level (Patel and Mishra, 2011) ${ }^{[19]}$

- The damage tissue produce by radiation prevented by Tinospora cordifolia (Pandey et al.; 2012) ${ }^{[18]}$.

- The powder of the stem is creamish brown or dark brown and its characteristics is odor, bitter taste and used for dyspepsia, fever and urinary diseases (Tiwari et al.; 2018) [34].

\section{Conclusion}

T.cordifolia is believed to be a medicinal plant which contains good nutritional value. It is mainly used in extract form for treatments since ancient times. For making it more easily consumable a study was done to evaluate the nutritional value of Giloy plant. It may be concluded that various Giloy based products like juice, cookies, RTS etc are attempt to make and it is found that addition of Giloy enhances nutritional and medicinal value of the prepared products. Slight amount of Giloy powder gradually increases nutritional value and utility value of cookies.

T.cordifolia based products comprises more nutritional value as compare to other artificial food products. Sensory attributes of products may decrease but are acceptable and can be ignore. Therefore, T.cordifolia may be used not only as a medicinal remedy but can also be used as value added product which enhances food quality and its nutritional value. It can be used for fortification of various food products which contain less nutritive value.

\section{References}

1. Abiramasundari G, Gowda, CMM, Pampapathi, G, Praveen S, Shivamurugan S, Vijaykumar M, et al. Ethnomedicine based evaluation of osteoprotective properties of T.cordifolia on in vitro and in vivo model systems. Biomedicine and pharmaco theraphy. 2017; 87:342-354.

2. Aher VD, Wahi A. Pharmacological study of Tinospora cordifolia as an immunomodulator. Int. J. Of Current Pharma. Res. 2010; 2(4):52-54.

3. Anonymous. The Ayurvedic pharmacopoeia of India. Department of AYUSH, Ministry of Health \& FW, New Delhi. 2001; 1(1):53-55.

4. Balandrin MF, Klocke JA, Wurtele ES, Bollinger WH. Natural Plant Chemicals: Sources of Industrial and Medicinal Materials. Science 1985; 228:1154-1160.

5. Chaudhari S, Shaikh N. Guduchi - the best ayurvedic herb. The pharma innovation Journal. 2013; 2(4):97-102.

6. Dhama K, Sachan S, Khandia R, Munjal A, Iqbal HMN, et al. Medicinal and beneficial health applications of Tinospora cordifolia (Guduchi): A miraculous herb countering various diseases/disorders and its immunomodulatory effects. Recent patens on endocrine. Metabolic and Immune drug discovery. 2017; 10(2):96111.

7. Gupta R, Sharma V. Ameliorative effects of T.cordifolia root extract on histopathological and biochemical changes induced by aflatoxin-b(1) in mice kidney. Toxicol Int. 2011; 18:94-98. 
8. Jagetia GC, Rao SK. Evaluation of the antineoplastic activity of guduchi (Tinospora cordifolia) in ehrlich ascites carcinoma bearing mice. Biol Pharm Bull. 2006; 29:460-466.

9. Kalikae MV, Thawani VR, Varadpande UK, Santakke SD, Singh RP, Khiyani RK. Immunomodulatory effect of T.cordifolia extract in HIV positive patients. Ind. J Pharmacol. 2008; 40:107-110.

10. Kim SK, Kim HJ, Choi SE, Park KH, Choi HK, Lee MW. Antioxidative and inhibitory activities on nitric oxide (NO) and prostaglandin E2 (COX-2) production of flavonoids from seeds of prunustomentosa Thunberg. Arch Pharm Res. 2008; 31:424-428.

11. Lv J, Xu D, Perkovic V, Ma X, Johnson DW, Woodward, M. Corticosteroid therapy in IgA nephropathy. J Am Soc Nephrol. 2012; 23:1108-16.

12. Maurya R, Handa SS. Tinocordifolin, a sesquiterpene from Tinospora cordifolia. Phytochem. 1998; 49:13431346.

13. McKeown E, Bykerk VP, Deleon F, Bnner A, Thorne C, Hitchon CA. Quality assurance study of the use of preventative therapies in glucocorticoid-induced osteoporosis in early inflammatory arthritis: Result from the CATCH cohort. Rheumatology (Oxford). 2012; 51:1662-1669.

14. Mittal J, Sharma MM, Batra A. Tinospora cordifolia: a multipurpose medicinal plant. Journal of Medicinal Plants Studies. 2014; 2(2):32-47.

15. Mukherjee R, De-UK, Ram GC. Evaluation of mammary gland immunity and therapeutic potential of Tinospora cordifolia against bovine subclinical mastitis. Trop Anim Health Prod. 2010; 42:645-651.

16. Nile SH, Khobragade CNN. Determination of nutritive value and mineral elements of some important medicinal plants from western part of India. J Med Plants. 2009; 8:79-88

17. Panchabhai TS, Kulkarni UP, Rege NN. Validation of Therapeutic Claims of Tinospora cordifolia: A Review Phytother.Res. 2008; 22:425-441.

18. Pandey M, Surendra K, Vyas Mk, Sharma R. "T.cordifolia: A climbing shrub in health care management." International journal of pharmaceutical \& biosciences. 2012; 3(4):612-628.

19. Patel MB, Mishra S. Hypoglycemic activity of alkaloidal fraction of Tinospora cordifolia. Phytomedicine. 2011; 18:1045-1052.

20. Patel SS, Shah RS, Goyal RK. Antihyperglycemic, antihyperlipidemic and antioxidant effects of Dihar, a poly herbal ayurvedic formulation in streptozotocin induced diabetic rats. Indian J Exp Biology. 2009; 47:564-570.

21. Rout GR. Identification of Tinospora cordifolia (Wild.) Miers ex Hook F \& Thoms using RAPD markers. Z Naturforsch C. 2006; 61:118-22.

22. Sarala M, Velu V, Anandharamakrishnan C, Singh RP. Spray drying of Tinospora cordifolia leaf and stem extract and evaluation of antioxidant activity. J Food Sci Technol. 2012; 49(1):119-122.

23. Sharma P, Parwar J, Verma P, Goyal PK. Radiationinduced testicular injury and it's amelioration by T.cordifolia (An Indian medicinal plant) extract. Evid based comp altern Med. 2012; 47:643-647.

24. Sharma P, Velu V, Indrani D, Singh RP. Effect of dried Guduchi (T.cordifolia) leaf powder on rheological, organoleptic and nutritional characteristics of cookies. Food research international. 2013; 50:704-709.
25. Singh B, Sharma ML, Gupta DK, Atal CK, Arya RK. (). Protective effect of Tinospora cordifolia meirs on carbon tetrachloride induced hepatotoxicity.Ind.J.Pharmacol. 1984; 16:139-142.

26. Singh BG, Warrior RR. Tinsospora cordifolia. Indian for. 2004; 130:1806.

27. Singh RP, Banerjee S, Kumar PVS, Raveesha KV, Rao AR. Tinospora cordifolia induces enzymes of carcinogen/drug metabolism and antioxidant system, and inhibits lipid peroxidation in mice. Phytomedicine. 2006; 13:74-84.

28. Singla A, Priya Akant Mr, Singla P. "Review of biological activities of T. cordifolia." Webmed central pharmaceutical sciences, 2010, 1(9).

29. Sinha K, Mishra NP, Singh J, Khanuja SPS. Tinospora cordifolia, a reservoir plant for therapeutic application. Indian Journal of Traditional Knowledge. 2004; 3(3):257270.

30. Soham S, Shyamasree G. T. cordifolia: One plant, many roles. Ancient science of life. 2012; 31(4):151-159.

31. Sood S. Studies on the nutritional evaluation of dietetic and sugar based Giloy (T.cordifolia) beverage. Nutrition \& Food Science International Journal. 2016; 1(5):NFSIJ.MS.ID.555-572.

32. Soudamini E, Senthil GM, Panayappan L, Duvakar MC. Herbal remedies of madugga tribes of siruvani forest, South India. Natural product Radiance. 2005; 4(6):492499.

33. Sundarraj S, Thangam R, Sreevani V, Kaveri K, Gunasekaran P, Achiraman S. Y-Sitosterol from acacia nilotica L. induces G2/M cell cycle arrest and apopyosis through c-Myc suppression in MCF-7 and A549 cells. J Ethnopharmcol. 2012; 141:803-809.

34. Tiwari P, Nayak SK, Prusty Sahu PK. Phytochemistry and pharmacology of T. cordifolia, Syst, Rev, Pharm. 2018; 9:70-78.

35. Upadhaya AK, Kumar K, Kumar A, Mishra HS. Tinospora cordifolia (Wild.) Hook. F. and Thoms. (Guduchi)-alidation of the Ayurvedic pharmacology through experimental and clinical studies. Int J Ayurveda Res. 2010; 1:112-121.

36. Upadhyay PR, Sharma V, Anita KV. Assessment of the multifaceted immunomodulatory potential of the aqueous extract of T.cordifolia. Res J Chem Sci. 2011; 1:71-79.

37. Vashist N, Drabu S, Nand P, Arora P. "Treatment strategies for monkey malaria" Research journal of pharmaceutical biological and chemical sciences. 2011; 2(4):79-97.

38. Wadood N, Wadood A, Shah SAW. Effect of T.cordifolia on blood glucose \& total lipid levels of normal \& Alloxendiabetic rabbit, planta medica. 1992; 58(2):131. 